\title{
DEZ ANOS CONTRIBUINdo PARA MEMÓRIA dA GIÊNCIA: REVISTA LATINO-AMERICANA DE ENFERMAGEM
}

\author{
Maria Helena Palucci Marziale ${ }^{1}$ \\ Isabel Amélia Costa Mendes²
}

O ano de 2003 marca o primeiro decenário da Revista Latino-americana de Enfermagem-RLAEnf.

A busca pela excelência da qualidade editorial impulsiona a instrumentalização permanente dos membros da Comissão de Editoração e da equipe de apoio técnico desta Revista, por intermédio da participação de cursos e reuniões sobre editoração científica, bem como através de intercâmbios com editores brasileiros e internacionais. $A$ afiliação à Associação Brasileira de Editores Científicos - ABEC possibilitou à RLAEnf mudanças e inovações no estilo, no formato e em seu modelo de gestão, adequando-a aos padrões internacionais de editoração e expandindo sua visibilidade na comunidade científica.

No que tange à normalização destacam-se as mudanças ocorridas nas normas de publicação dos artigos e a adoção do estilo Vancouver ${ }^{(1)}$, proporcionando maior clareza na apresentação dos textos; destaque ao posicionamento dos autores frente às pesquisas apresentadas; maximização do aproveitamento de espaço na edição, resultando em um maior número de artigos por fascículo e as indexações da RLAEnf em novas bases de dados ${ }^{(2)}$.

As bases de dados representam importante meio de divulgação do conhecimento produzido. Para ser incluída em uma base de dados a revista é submetida a um processo rigoroso de avaliação, sendo considerados os padrões básicos de publicação, o conteúdo editorial, a regionalidade dos autores, dados de citações referentes aos autores, a regularidade e a pontualidade das publicações, o seguimento das convenções internacionais de edição, a representação geográfica da revista e os elementos bibliográficos em língua inglesa, em caso de bases de dados internacionais.

A indexação da RLAEnf em bases de dados é uma das principais estratégias para ampliar sua visibilidade. Atualmente, esta Revista está incluída nas seguintes bases de dados:

MEDLINE - base de dados da literatura internacional da área médica e biomédica, produzida pela National Library of Medicine. Contém referências bibliográficas e resumos de mais de 4000 títulos de revistas biomédicas publicadas nos Estados Unidos e em outros 70 países. Reúne aproximadamente 11 milhões de registros da literatura desde 1966 até o momento, que cobrem as áreas de medicina, biomedicina, enfermagem, odontologia, veterinária e ciências afins.

LILACS - Literatura Latino-Americana e do Caribe em Ciências da Saúde, é uma base de dados cooperativa do Sistema BIREME. Compreende a literatura relativa às Ciências da Saúde publicada nos países da Região das Américas, a partir de 1982. Contém artigos de aproximadamente 670 revistas das mais conceituadas da área da saúde, atingindo mais de 150.000 registros, e outros documentos tais como: teses, capítulos de teses, livros, capítulos de livros, anais de congressos ou conferências, relatórios técnico-científicos e publicações governamentais.

CAB HEALTH - especializada em nutrição humana, doenças tropicais parasitárias notificáveis e plantas medicinais. Oferece acessos a resumos da literatura científica mundial desde 1973 com cobertura de periódicos, livros, relatórios de pesquisa, patentes, teses, anais de congressos, relatórios, informações sobre países em desenvolvimento e outras literaturas de difícil obtenção em inglês e outros idiomas. Contém mais de 860.000 registros. Praticamente todas as palavras podem ser pesquisadas, permitindo o fácil acesso a essa importante coleção de referências à literatura relacionada à saúde humana e doença em âmbito internacional.

Editores da Revista Latino-Americana de Enfermagem da Escola de Enfermagem de Ribeirão Preto, da Universidade de São Paulo, Centro Colaborador da OMS para o desenvolvimento da pesquisa em enfermagem: ${ }^{1}$ Professor Livre-Docente, e-mail: marziale@eerp.usp.br; ${ }^{2}$ Professor Titular, e-mail: iamendes@eerp.usp.br 
CAB ABSTRACTS - base bibliográfica compilada pela CABI Publishing. Cobre a literatura sobre pesquisas significativas e de desenvolvimento nas áreas de agricultura, floresta, aspectos sobre a saúde humana, nutrição humana, saúde animal e controle e preservação de recursos humanos. Mais de 4 milhões de registros foram incluídos na base de dados desde sua informatização, em 1973. Esses registros estão disponíveis através de ampla gama de produtos e serviços nos formatos impresso e eletrônico.

CINAHL/Cumulative Index to Nursing \& Allied Health Literature - fonte confiável de informação para a literatura profissional de enfermagem, aliada à saúde, biomedicina e cuidado à saúde. Durante quarenta anos, o Cumulative Index to Nursing \& Allied Health Literature realiza a indexação de periódicos em língua inglesa, assim como a seleção daqueles em língua estrangeira, relacionados à enfermagem e outras áreas especializadas do cuidado à saúde. A base de dados também inclui materiais relevantes de dezessete disciplinas relacionadas à área da saúde, além da biomedicina, administração, ciências comportamentais, biblioteconomia em ciências da saúde e direitos do consumidor. A base de dados CINAHL traz referências a livros, capítulos, panfletos, materiais audiovisuais, teses, softwares educativos, anais de congressos selecionados, padrões da prática profissional, ações da prática em enfermagem, avaliações críticas e instrumentos de pesquisa.

ULRICH'S/International Periodicals Directory - publicada desde 1979 pela R.R. Bowker/Reed Elsevierlnc, possui dados de mais de 210.000 publicações regulares e irregulares provenientes de 200 países.

SciELO/Scientific Electronic Library Online - biblioteca eletrônica que abrange uma coleção selecionada de periódicos científicos, especialmente desenvolvida para responder as necessidades da comunicação científica nos países em desenvolvimento e particularmente de países da América Latina e do Caribe. A RLAEnf faz parte da coleção SciELO/ Brasil, que é o resultado de um projeto de pesquisa da FAPESP - Fundação de Amparo à Pesquisa do Estado de São Paulo, em parceria com a BIREME - Centro Latino-Americano e do Caribe de Informação em Ciências da Saúde, atualmente contando também com o apoio do CNPq - Conselho Nacional de Desenvolvimento Científico e Tecnológico. BDENF/Base de Dados em Enfermagem - base de dados bibliográficos especializada em Enfermagem. É desenvolvida pela Biblioteca J. Baeta Vianna, do Campus da Saúde/Universidade Federal de Minas Gerais - UFMG. Criada em 1988, objetiva facilitar o acesso e a difusão das publicações da área, normalmente ausentes das bibliografias nacionais e internacionais. Desenvolveu-se com o patrocínio do PRODEN - Programa de Desenvolvimento da Escola de Enfermagem/ UFMG e do convênio estabelecido com o Centro Latino-Americano e do Caribe de Informação em Ciências da Saúde BIREME, com o compromisso de alimentar a Base de Dados LILACS. Inclui referências bibliográficas e resumos de documentos convencionais e não convencionais, tais como: livros, teses, manuais, folhetos, congressos, separatas e publicações periódicas, gerados no Brasil ou escritos por autores brasileiros e publicados em outros países.

A partir dos próximos meses a RLAEnf estará também incluída em duas novas bases de dados:

PSYCINFO - da American Psychologial Association, contém resumos e citações de literatura em ciências do comportamento e saúde mental. Inclui material de relevância para psicólogos e outros profissionais em relação a temas voltados à psiquiatria, negócios, educação, ciências sociais, neurociências, medicina e trabalho social. Atualmente possui resumos de 1.300 revistas, informes, livros, teses, etc publicados no mundo inteiro.

CUIDEN - produzida pela Fundação INDEX da Espanha, contém dados bibliográficos de enfermagem e cuidados à saúde. Possui acesso livre e os documentos são editados em espanhol.

Em relação à publicação, ao longo dos seus dez anos a RLAEnf editou 11 volumes, 42 fascículos regulares e 3 especiais, e 578 artigos de autoria de enfermeiros e de profissionais de áreas afins oriundos das várias regiões do Brasil e de outros países como: Chile, Argentina, Colômbia, Portugal, Estados Unidos, Cuba.

A periodicidade da RLAEnf também sofreu alterações, saltando de semestral para trimestral e, desde 2002, circula bimestralmente, visando a atender a demanda reprimida de manuscritos recebidos para publicação.

Consultores competentes auxiliam na análise crítica dos manuscritos, zelando pela qualidade e consistência dos artigos publicados.

Pelo exposto, conclui-se que a RLAEnf vem atendendo sua missão de divulgar o conhecimento produzido pela Enfermagem e ciências afins, colaborando na fundamentação das ações profissionais na assistência de enfermagem, no ensino e na investigação científica. 
O sucesso é decorrente do empenho de docentes que compõem a Comissão de Editoração e o Conselho Diretor da Revista, de seus funcionários, dos membros do Conselho Editorial, dos conselheiros ad hoc, dos pesquisadores que confiam a divulgação de seus artigos. Esse trabalho é reconhecido pelos quase 1000 assinantes da RLAEnf, foco central dos esforços empreendidos. Menção especial deve ser feita à Organização Mundial da Saúde/Organização PanAmericana da Saúde ${ }^{(3)}$, incentivadoras da criação deste periódico, à Fundação Kellogg ${ }^{(4)}$, patrocinadora da Revista no período de 1993 a 1996, bem como à FAPESP e ao CNPq, cujo apoio imprescindível permite o financiamento parcial da RLAEnf.

A todos esses atores, os agradecimentos da RLAEnf, que ao completar 10 anos reitera seu compromisso com a Enfermagem, em prol do avanço da ciência e do cuidado em saúde.

\section{REFERÊNCIAS BIBLIOGRÁFICAS}

1. International Committe of Medical Editors. Uniform requeriments for manuscripts submitted to biomedical journals, New Engl J Med 1997; 336:309-16.

2. Marziale MHP, Mendes IAC. Perfil da produção de uma publicação científica: Revista Latino-Americana de Enfermagem. Rev Bras Enfermagem 2003; 55(1):31-5.

3. Mendes IAC. Carta ao leitor. Rev Latino-am Enfermagem 1993 janeiro; 1(1):7-8.

4. Aguillar OM, Alencastre MB. Editorial. Rev Latino-am Enfermagem 1993 julho; 1(2):1-2. 


\title{
TEN YEARS CONTRIBUTING TO THE MEMORY OF SCIENCE: REVISTA LATINO-AMERICANA DE ENFERMAGEM
}

\author{
Maria Helena Palucci Marziale ${ }^{1}$ \\ Isabel Amélia Costa Mendes ${ }^{2}$
}

2003 is the $10^{\text {th }}$ years anniversary of the Revista Latino-Americana de Enfermagem-RLAEnf.

The search for the excellence of the editorial quality stimulates the continuous instrumentalization of the members of the Editorial Board and the technical staff of this Journal, through the participation in courses and meetings on scientific editing as well as by means of exchanges with editors from Brazil and abroad. The affiliation to the Brazilian Association of Scientific Editors - enabled the RLAEnf to develop changes and innovations in its style, form and management model, adequating them to the international patterns as well as at extending its visibility within the scientific community.

With respect to the normalization, it is important to emphasize the changes in publication guidelines with the adoption of the Vancouver ${ }^{(1)}$ style, enabling more clarity in the presentation of the manuscripts, giving special prominence to the authors and to the to the research presented, maximizing the utilization of its edition space, what resulted in a higher number of articles published by issue and also in the indexation of the Journal in new databases ${ }^{(2)}$.

The databases represent important means of disseminating the knowledge produced. In order to be indexed, the journal is submitted to a strict evaluation process in which they consider the publication standards, editorial content, authors' origin, citations, regularity and accuracy, the follow-up of international agreements on edition, the journal's geographical representation and the bibliographical elements in English, in case of international databases.

Thus, the indexation of RLAEnf in new databases is one of its main strategies to increase its visibility. Nowadays, the Journal is included in the following databases:

MEDLINE - it is a database on international literature, produced by the National Library of Medicine - NLM, which gathers bibliographic references and summaries of more than 4000 biomedical journals published in the United States and in other 70 countries. There are approximately 11 million records on biomedical literature since 1966 which cover medicine, nursing, odontology, veterinary and preclinical sciences.

LILACS - Latin American and Caribbean Literature on the Health Sciences is a BIREME System's cooperative database which covers literature related to the health sciences and has been published in countries of the Region since 1982. It contains articles from about 670 of

the most well-known journals in the medicine field, reaching approximately more than 150,000 records and other documents, such as: theses, chapters of theses, books, chapters of books, congress and conference proceedings, technical and scientific reports and governmental publications.

CAB HEALTH - specialized in human nutrition, tropical diseases, parasitic diseases and parasitology and medicinal. It provides access to abstracts of the world's research literature from 1973 to present with coverage of English and foreign language journals, books, research reports, patents and standards, dissertations, conference proceedings, annual reports, developing country information and other difficult to obtain literature. The database contains over 860,000 records with 45,000 records added annually. Virtually every word is searchable, allowing for easy access to this important collection of references to international human health and diseases literature.

CAB ABSTRACTS - is a bibliographic database compiled by CABI Publishing. It covers the significant research and

Editors of Latin American Journal of Nursing of Ribeirão Preto of the University of São Paulo at Ribeirão Preto College of Nursing - WHO Collaborating Centre for Nursing Research Development: ${ }^{1}$ Associate Professor, e-mail: marziale@eerp.usp.br; ${ }^{2}$ Full Professor, e-mail: iamendes@eerp.usp.br 
development literature in the fields of agriculture, forestry, aspects of human health, human nutrition, animal health and the management and conservation of natural resources. Over four million records have been added to the database since its computerization in 1973. These records are made available through a wide range of products and services both printed and electronic.

CINAHL/Cumulative Index to Nursing \& Allied Health Literature - a reliable database that covers nursing and allied health literature. In forty years, the Cumulative Index to Nursing \& Allied Health Literature has indexed periodicals in English and selected periodicals in other languages but related to health care areas. The database includes material linked to sixteen disciplines related to the health area, besides biomedicine, administration, behavioral sciences, and consumer's rights. The database contains references of books, chapters, audiovisual materials, dissertations, educative softwares, proceedings, professional practice patterns, nursing practice, critical evaluation and research instruments.

ULRICH'S/International Periodicals Directory - published since 1979 by the R.R. Bowker/Reed Elsevierlnc, contains more data on more than 210.000 regular and irregular publications from 200 countries.

SciELO/Scientific Electronic Library Online - is an electronic library covering a selected collection of scientific journals, specially developed to respond to the scientific communication needs of developing countries, mainly from Latin America and Caribbean islands. The library is an integral part of a project being developed by FAPESP - Fundação de Amparo à Pesquisa do Estado de São Paulo, in partnership with BIREME - the Latin American and Caribbean Center on Health Sciences Information. The Project is also supported by CNPq - Conselho Nacional de Desenvolvimento Científico e Tecnológico.

BDENF/Base de Dados em Enfermagem - a Nursing database developed by the J. Baeta Vianna library - Health Campus/Federal University of Minas Gerais. It was created in 1988, with the purpose to facilitate the access and dissemination of publications in the area. It was supported by PRODEN - Development Program/ Nursing School Federal University of Minas Gerais in agreement with BIREME the Latin American and Caribbean Center on Health Sciences Information, with the commitment to fulfill the LILACS database. It includes bibliographical references and abstracts of documents such as: books, dissertations, manuals, congresses, periodical publications generated in Brazil or written by Brazilian authors and published in other countries.

Also, the RLAEnf is looking forward to being included in two new databases:

PSYCINFO - is an electronic database maintained by the American Psychological Association, that provides abstracts and citations to the scholarly literature in the behavioral sciences and mental health. The database includes material of relevance to psychologists and professionals in related fields such as psychiatry, management, business education, social science, neuroscience, law, medicine and social work. Nowadays, there are abstracts of 1.300 journals, books and theses published all around the world.

CUIDEN - produced by INDEX Foundation in Spain and containing data on Nursing and related health sciences. The access is free and the documents are in Spanish.

With respect to the publication, in its ten years, the RLAEnf published 11 volumes, 42 regular issues and 3 special ones, and 578 articles authored by nurses and health professionals from different regions of Brazil and other countries such as: Argentina, Chile, Colombia, Cuba, Portugal and USA.

The periodicity of the RLAEnf has changed from a semester to a trimester basis and since 2002, the Journal is published bimonthly in order to fulfill the demand of articles for publication.

Renowned experts are responsible for the critical analysis of the manuscripts, assuring the quality and consistency of the articles published.

Therefore, the RLAEnf is striving to achieve its goal of disseminating the knowledge produced in Nursing and related areas, collaborating in the development of fundamental foundations for the professional action in nursing care, teaching and research.

The success is a result of the joined effort of faculty who are members of the Editorial Committee and Executive Council, the staff, members of the Editorial Board, the ad hoc advisors and researchers who trust the dissemination of their articles to RLAEnf. This work is recognized by the 1000 subscribers. It is also important to mention the World Health Organization/ Pan American Health Organization ${ }^{(3)}$, that stimulated the creation of the journal, and to Kellogg 
Foundation ${ }^{(4)}$, that supported this Journal from 1993 to 1996 , as well as to FAPESP and CNPq, whose financial support enabled the maintenance of this Journal.

The RLAEnf thanks all these actors and reiterates its commitment to Nursing and the improvement of science and health care.

\section{REFERENCES}

1. International Committee of Medical Editors. Uniform requirements for manuscripts submitted to biomedical journals, New Engl J Med 1997; 336:309-16.

2. Marziale MHP, Mendes IAC. Perfil da produção de uma publicação científica: Revista Latino-Americana de Enfermagem. Rev Bras Enfermagem 2003; 55(1):31-5.

3. Mendes IAC. Carta ao leitor. Rev Latino-am Enfermagem 1993 janeiro; 1(1):7-8.

4. Aguillar OM, Alencastre MB. Editorial. Rev Latino-am Enfermagem 1993 julho; 1(2):1-2 


\title{
DIEZ AÑOS CONTRIBUYENDO CON LA MEMORIA DE LA CIENCIA: REVISTA LATINOAMERICANA DE ENFERMERÍA
}

\author{
Maria Helena Palucci Marziale ${ }^{1}$ \\ Isabel Amélia Costa Mendes²
}

El año del 2003 marca el primer decenio de la Revista Latinoamericana de Enfermería.

La búsqueda por la excelencia de la calidad editorial impulsa la instrumentalización de los miembros de la comisión editorial y del equipo de apoyo técnico de esta revista, por intermedio de la participación en cursos y reuniones sobre editoriación científica, así como también, a través de intercambios con editores brasileños e internacionales. La afiliación a la Asociación Brasileña de Editores Científicos - ABEC hizo posible a la RLAEnf cambios e innovaciones en el estilo, en el formato y en su modelo de gestión, adecuando los patrones internacionales de editoriación y expandiendo su visibilidad en la comunidad científica.

En lo que se refiere a la normatización se destacan los cambios ocurridos en la normas de publicación de los artículos y la adopción del estilo Vancouver ${ }^{(1)}$, proporcionando mayor claridad en la presentación de los textos; mayor destaque al posicionamiento de los autores frente a las investigaciones presentadas; maximización del aprovechamiento del espacio en la edición, trayendo como resultado un mayor número de artículos por fascículos y las indexaciones de la RLAEnf en nuevas bases de datos ${ }^{(2)}$.

Las bases de datos representan un importante medio de divulgación del conocimiento producido. Para ser incluida en una base de datos la revista es sometida a un proceso riguroso de evaluación, siendo considerados los patrones básicos de publicación, el contenido editorial, la regionalidad de los autores, datos de la referencias a los autores, la regularidad y la puntualidad de las publicaciones, el seguimiento de las convenciones internacionales de edición, la representación geográfica de la revista y los elementos bibliográficos en lengua inglesa, en caso de bases de datos internacionales.

La indexación de la RLAEnf en bases de datos es una de las principales estrategias para ampliar su visibilidad. Actualmente, esta revista está incluida en las siguientes bases de datos:

MEDLINE - Base de datos de la literatura internacional del área médica y biomédica, producida por la National Library of Medicine. Contiene referencias bibliográficas y resúmenes de más de 4000 títulos de revistas biomédicas publicadas en los Estados Unidos y en otros 70 países. Reúne aproximadamente 11 millones de registros de la literatura desde 1966 hasta el momento, los cuales cubren las áreas de medicina, biomedicina, enfermería, odontología, veterinaria y ciencias afines.

LILACS - Literatura Latinoamericana y del Caribe en Ciencias de la Salud, es una base de datos cooperativa del sistema BIREME. Comprende la literatura relacionada con las Ciencias de la Salud publicada en los países de la Región de las Américas, a partir de 1982. Contiene aproximadamente 670 revistas de las más importantes en el área de la salud, alcanzando más de 150.000 registros y otros documentos tales como: tesis, capítulos de tesis, libros, capítulos de libros, anales de congresos o conferencias, informes técnico-científicos y publicaciones gubernamentales.

CAB HEALTH - Especializada en nutrición humana, enfermedades tropicales y parasitarias notificables y plantas medicinales. Ofrece acceso a resúmenes de la literatura científica mundial desde 1973 con cobertura de periódicos, libros, informes de investigación, patentes, tesis, anales de congresos, informes e informaciones sobre países en desarrollo y otras literaturas de difícil obtención en ingles y en otros idiomas. Contiene más de 860.000 registros.

Editores de la Revista Latinoamericana de Enfermería de la Escuela de Enfermería de Ribeirão Preto de la Universidad de São Paulo, Centro Colaborador de la OMS para el desarrollo de la investigación en enfermería: ${ }^{1}$ Professor Libre-Docente, correo electrónico: marziale@eerp.usp.br;

${ }^{2}$ Professor Titular, correo electrónico: iamendes@eerp.usp.br 
Prácticamente todas las palabras pueden ser investigadas, permitiendo el fácil acceso esta importante colección de referencias a la literatura relacionada con la salud humana y la enfermedad en el ámbito internacional.

CAB ABSTRACTS - Base bibliográfica compilada por la CABI Publishing. Cubre la literatura sobre investigaciones significativas y de desarrollo en las áreas de agricultura, floresta, aspectos sobre la salud humana, nutrición humana, salud animal y control y preservación de recursos humanos. Más de 4 millones de registros fueron incluidos en la base de datos desde su informatización, en 1973. Estos registros están disponibles a través de una amplia gama de productos y servicios en los formatos impreso y electrónico.

CINAHL/Cumulative Index to Nursing \& Allied Health Literature - Fuente confiable de información para literatura profesional de enfermería, relacionada con salud, biomedicina y cuidado de la salud. Durante cuarenta años, el Cumulative Index to Nursing \& Allied Health Literature realiza la indexación de revistas en Lengua inglesa, así como también la selección de aquella en lengua extranjera relacionadas con la enfermería y otras áreas especializadas del cuidado de la salud. La base de datos también incluye materiales relevantes de 17 disciplinas relacionadas con el área de la salud, además de la biomedicina, administración, ciencias comportamentales, biblioteconomía en ciencias de la salud y derechos del consumidor. La base de datos CINAHL trae referencias de libros, capítulos, panfletos, materiales audiovisuales, tesis, softwares educativos, anales de congresos seleccionados, patrones de práctica profesional, acciones de la práctica en enfermería, evaluaciones criticas e instrumentos de investigación.

ULRICH'S/International Periodicals Directory - Publicada desde 1979 por la R.R. Bowker/Reed Elsevierlnc, posee datos de mas de 210.000 publicaciones regulares e irregulares de 200 países.

SciELO/Scientific Electronic Library Online - Biblioteca electrónica que cubre una colección seleccionada de revistas científicas, especialmente desarrollada para responder a las necesidades de la comunicación científica en los países en desarrollo y principalmente en los países de la América latina y del caribe. La RLAEnf hace parte de la colección SciELO/Brasil, que es el resultado de un proyecto de investigación de FAPESP- Fundación de Amparo a la Investigación del Estado de São Paulo, en asocio con el BIREME Centro Latinoamericano e del Caribe de Información en Ciencias de la Salud, contando también en la actualidad con el apoyo del CNPq - Consejo Nacional de Desarrollo Científico y Tecnológico.

BDENF/Base de datos en Enfermería - Base de datos especializada en enfermería. Es desarrollada por la Biblioteca J. Baeta Viana, del Campus de Salud de la Universidad Federal de Minas Gerais - UFMG. Creada en 1988, busca facilitar el acceso y la difusión a las publicaciones del área, normalmente ausentes de las bibliografías nacionales e internacionales. Se desarrolla con el patrocinio del PRODEN - Programa de Desarrollo de la Escuela de Enfermería/ UFMG y del convenio establecido con el Centro Latinoamericano y del Caribe de Información en Ciencias de la SaludBIREME, con el compromiso de alimentar la base de datos LILACS. Incluye referencias bibliográficas y resúmenes de documentos convencionales y no convencionales, tales como, libros, tesis, manuales, folletos, congresos, separatas y publicaciones periódicas, generados en el Brasil o escritos por autores brasileños y publicados en otros países.

A partir de los próximos meses la RLAEnf estará también incluida en dos nuevas bases de datos.

PSYCINFO - de la American Psychological Association, contiene resúmenes y citaciones de literatura en ciencias del comportamiento y salud mental. Incluye material de relevancia para psicólogos y otros profesionales en relación con temas orientados a la psiquiatría, los negocios, la educación, las ciencias sociales, las neurociencias, medicina y trabajo social. Actualmente posee resúmenes de 1300 revistas, informes, libros, tesis, etc., publicados en el mundo entero.

CUIDEN - Producida por las Fundación INDEX de España, contiene datos bibliográficos de enfermería y cuidados a la salud. Posee acceso libre y os documentos son editados en español.

En relación con la publicación, a lo largo de sus diez años la RLAEnf editó 11 volúmenes, 42 fascículos regulares y 3 especiales, 578 artículos de autoría de enfermeros y de profesionales de áreas afines oriundos de varias regiones del Brasil y de otros países como: Chile, Argentina, Colombia, Portugal, Estados Unidos, Cuba.

La periodicidad de la RLAEnf también sufrió alteraciones, saltando de semestral para trimestral y, desde el 2002, circula bimestralmente, buscando atender la demanda reprimida de manuscritos recibidos para publicación.

Consultores competentes ayudan en el análisis critico de los manuscritos, vigilando la calidad y consistencia de los artículos publicados. 
Por lo expuesto, se concluye que la RLAEnf viene atendiendo su misión de divulgr el conocimiento producido por enfermería y las ciencias afines, colaborando con la fundamentación de las acciones profesionales en la atención de enfermería, en la enseñanza y en la investigación científica.

El éxito se deriva del empeño de los docentes que componen la Comisión Editorial y el Consejo Director de la Revista, de sus funcionarios, de los miembros del Consejo Editorial, de los consejeros ad hoc, de los investigadores que confian en la divulgación de sus artículos. Ese trabajo es reconocido por los casi 1000 suscriptores de la RLAEnf, foco central de los esfuerzos emprendidos. Mención especial debe ser hecha a la Organización Mundial de la Salud/ Organización Panamericana de la salud ${ }^{(3)}$, precursoras de a creación de esta revista, a la Fundación Kellog ${ }^{(4)}$, patrocinadora de la revista en el periodo de 1993 a 1996, así como también a FAPESP y al CNPq, cuyo apoyo imprescindible permite el financiamiento parcial de la RLAEnf.

A todos estos actores, los agradecimientos de la RLAEnf, que al completar 10 años, reitera su compromiso con la enfermería en pro del avance de la ciencia y el cuidado en salud.

\section{REFERENCIAS BIBLIOGRÁFICAS}

1. International Committe of Medical Editors. Uniform requeriments for manuscripts submitted to biomedical journals, New Engl J Med 1997; 336:309-16.

2. Marziale MHP, Mendes IAC. Perfil da produção de uma publicação científica: Revista Latino-Americana de Enfermagem. Rev Bras Enfermagem 2003; 55(1):31-5.

3. Mendes IAC. Carta ao leitor. Rev Latino-am Enfermagem 1993 janeiro; 1(1):7-8.

4. Aguillar OM, Alencastre MB. Editorial. Rev Latino-am Enfermagem 1993 julho; 1(2):1-2. 